TURIZAM

Volume 13

Issue 1, 28-44 (2009)

\title{
Active Holiday in Mt. Zlatibor County
}

Jovan Plavša*

Jovan Romelić*

Dušan Ljubomir Vuksanović**

Received: June 2009 | Accepted: September 2009

\section{Abstract}

Active holiday presents a new stream in tourism development of Serbia. The most interesting types of active holiday in Serbia are: free and mountain biking, rafting, hiking, mountaineering, free climbing, orienteering, fishing, sailing, rowing, paragliding, cave exploring, skiing, survival in nature, zorbing, horse riding, etc. Zlatibor district is almost perfect area for developing active holiday, due to the nature beauties and diversity of landscape. The most atractive parts for developing active holiday in Zlatibor district are: Tara Mountain and Drina River Gorge, Zlatibor Mountain, Uvac River Gorge and Zlatar Mountain, Lim River Valley and Pester Highlands.

Key words: Active Holiday, Zlatibor County, Serbia

\section{Introduction}

Active holiday is a lifestyle form. The rule of thumb for active holiday reads that it is always an exciting travelling implying active participation of an individual to which unique challenges in nature are offered. There has always been adventurous travelling, most frequently emerging during the Renaissance (Plavša, 2007). Although its form has undergone smaller changes, it is still based on human curiosity. Travellers all over the world tend to more frequently abandon the prescribed routes and give over to the world of unknown. Man is probably the only one among species that would climb a mountain peak for mere curiosity or travel to other continents just for exploration purposes. People have always been interested in new cultures, impressive and unknown districts. Therefore, active tourism is not a new phenomenon both in theory and practice. Active tourism is a part of the market of special interest tourism, i.e. active holiday is a product of special interests market (Hall, Page, 2002).

* Departman of geography, tourism and hotel management, Novi Sad, pivoljak@yahoo.com; jromel@uns.ac.rs

** Manager in tourism 
Most of the authors define active holiday as "...responsible travel to foreign areas requiring physical and mental participation from the tourist and following the maximes of sustainability, protection of biodiversity and conservation of culture. Important elements are recreation and education, respect and contemplation, action and exercise" (www.active-tourism.com). According to H. Sung (1997), active holiday is ,a trip or travel with the specific purpose of activity participation to explore a new experience, often involving perceived risk or controlled danger associated with personal challenges, in a natural environment or exotic outdoor setting".

Serbia, with its highly attractive natural resources, is perceived as a new and preserved destination at modern tourism market of sophisticated taste. As such, Serbia may definitely become an alternative to traditional markets, but at the same time set itself challenging competitive tasks in the battle for active tourism development. This is supported by the importance and real perspectives in making the offer for active holiday in Serbia. Therefore, active holiday in Serbia should be considered as a significant segment of tourism market in the following period and one of key directions within new strategy of tourism development in Serbia.

The authors of the paper address to problems of active holiday in present and future tourism development in popular tourism region of Mt. Zlatibor County. The paper covers certain destinations of active tourism which most adequately reflect the present condition and also give clear guidelines for further development of tourism in the region.

\section{Mt. Zlatibor County and active holiday's development}

Mt. Zlatibor County is located in south-eastern part of Serbia, covering 6,142 $\mathrm{km}^{2}$ which makes it the largest county in Serbia (Statistical office of the Republic of Serbia). It comprises the municipalities: Bajina Basta, Kosjeric, Uzice, Pozega, Cajetina, Arilje, Priboj, Nova Varos, Prijepolje and Sjenica. The seat of the county is Uzice.

The area of the Mt. Zlatibor County is a specific tourist region in Serbia. With the aim to most comprehensively cover the phenomenon of active holiday, we have selected certain tourist destinations of active holiday. The process of destination selection did not follow administrative territorial division of Mt. Zlatibor County, but the destinations were selected according to the type of active holiday and their potential in future active holiday development and tourism development in this prosperous tourist region. However, the selection of five most prosperous destinations covered the whole territory of the County.

The paper analyses the following destinations of active holiday in Mt. Zlatibor County:

1. Mountain Tara and the valley of the Drina river,

2. Mountain Zlatibor,

3. The valley of the Uvac river and mountain Zlatar,

4. The valley of the Lim river

5. Pester Plateau.

All five destinations are specific in former tourism development of the County. The area of Mt. Zlatibor County belongs to south-eastern Serbia, covering the most of its territory, which assigns the key role to the County in both tourism and general development within the region.

The selection of five destinations is the most objective presentation of the current offer of active tourism in the County. The analysis of uniform development and interrelations of certain locations was the key criterion for conceptual organization of destinations consisting of one, two or several locations. For example, if mountain Tara is to be analysed, then it is inevi- 


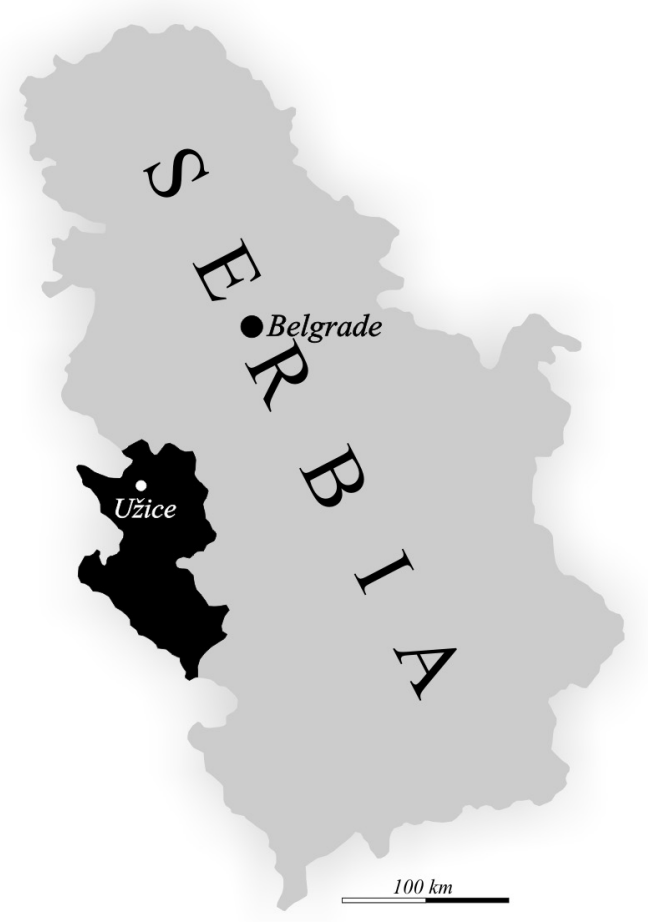

Map 1. Zlatibor County in Serbia

table to include the valley of the Drina river with regard to their parallel development and affirmation in tourism. Equivalent to this destination, another destination the valley of the Uvac river and mountain Zlatar, was selected. Zlatibor is the most frequently visited mountain and an independent destination and as such the subject of the research. Destination the valley of the Lim river covers only the area of Polimlje on the territory of Serbia and the mountains around the river. The destination Pester Plateau is the least developed from tourism aspect, but attractive and perspective destination for its natural resources.

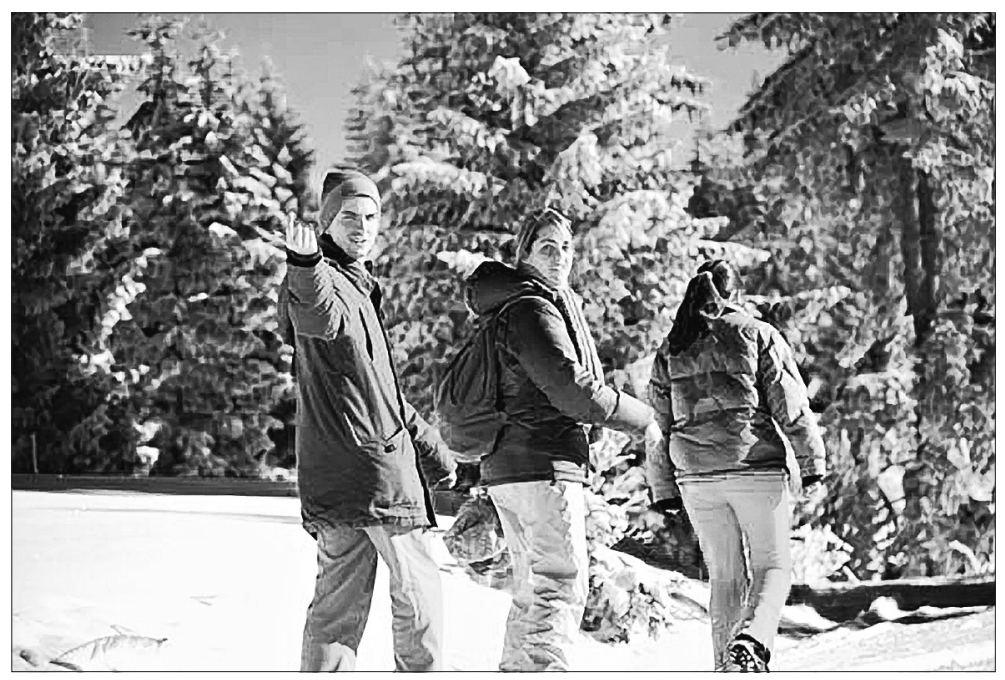

Figure 1. Hiking on the Kamena gora (Foto: D. Lj. Vuksanović, 2008) 
The area of Mt. Zlatibor County includes numerous natural values more or less popular in tourism. Affirmation of active holiday and tourism in general in the area should be based on sustainability principles. The most valuable natural resources of Mt. Zlatibor County are natural protected values: National Park Tara, Nature Park Zlatibor, areas of exceptional features Zaovine and Sargan - Mokra Gora, Special Nature Reserve Uvac, Pestersko polje and Gorge of the river Milesevka, as well as several Natural Monuments - Slapovi Sopotnice (waterfalls), Stopica pecina (cave), Potpećka pećina (cave) and Sveti bor at Kamena Gora.

Mountain Tara and the valley of the Drina river. Mountain Tara is located in the west end of Serbia in the border region with the Republic of Srpska. The largest portion of this mountain near the Drina river is at 1,00o to 1,200 $\mathrm{m}$ of altitude, with the highest peaks between 1,400 to $1,544 \mathrm{~m}$ (Zboriste).

The area is intersected by deeply cut river valleys - gorges and canyons, with the most striking canyon of the river Drina with powerful limestone walls over 1,00o $\mathrm{m}$ high. Besides the canyon of the Drina, there are also beautiful and wild canyons of the rivers Raca, Brusnice and Derventa in the area of Mt. Tara. "The queen of the mountains" in not only recognizable by its deep and wild canyons and gorges, but also by its dense autochthonous coniferous forests which identify it as the highest quality forest mountain in Serbia and Europe (Amidzic et al, 2007).

Among over 1,0oo flora species, the most valuable are 20 endemic species with the greatest value assigned to Pancic's spruce (Picea omorica). Mt. Tara was declared a national park covering the area of 19,175 ha in 1981 (Ilic, Stankovic, 2006).

Mountain relief, altitude and hydrographic objects in its area offer ideal conditions for active holidays. Since protected natural assets are in question tourism zoning plans are necessary to be realized through protection regimes of those assets. Depending on the type of protected natural value and the protection level, the content for active holiday will be allowed in zones of the $1^{\text {st }}$ and $2^{\text {nd }}$ degree of protection (Plavsa, Romelic, Stojanovic, 20o6; Stojanovic, 2007).

Current offer of active holiday. Destination Mt. Tara and the valley of the river Drina offers to all age groups of tourists unrestricted possibilities for undertaking various types of activities, depending on their interest, health and physical condition.

This destination has been offering the following activities within the scope of active holiday for several years: hiking and mountaineering, free biking ${ }^{1}$ and mountain cycling, orientation in nature, rafting, skiing, horse riding, sports fishing, sailing and rowing.

Hiking and mountaineering. There are 18 well marked trails for hiking and mountaineering with the total length of $120 \mathrm{~km}$. The starting points for thee routes are mainly at Mitrovac and Predov krst, with the length of the routes ranging from 1.5 to $18 \mathrm{~km}$. Mountain maps are recommended for use and could be found at information desks in the National park. Also there is a jogging track $(1.5 \mathrm{~km})$ at Mt. Tara.

Free biking and mountain cycling. The terrain totally meets the needs for formation of trails of various difficulty levels, ranging from the easiest to most difficult. The realisation of the project "Taro Cycle" will make Mt. Tara the first domestic national park with marked cycling tracks. The project will involve marking of 24 tracks leading from Kaluđerske bare, Mitrovac or Predov Krst over Perucac, lake Zaovine, Borovo brdo, Kremna or Mokra Gora up to Mt.

1 Freebiking is a hobby, love, passion and for most of them unique way of meeting new outdoor settings. As such, it does not have anything in common with cycling as sport. 


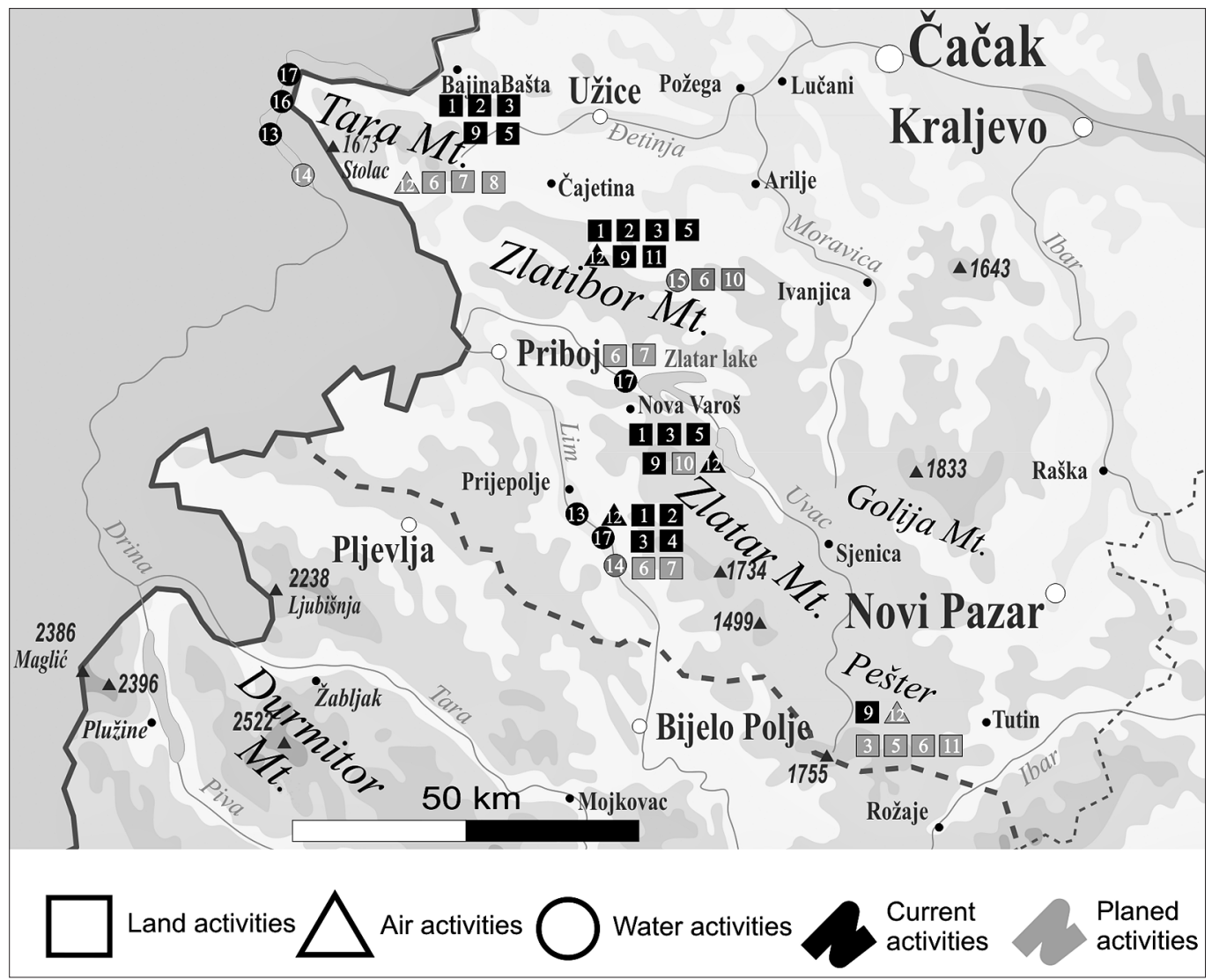

Map 2. Location of present and proposed forms of active holiday in the County (Base Geokarta; adapted by S. Dokmanovic)

Legend: 1. Hiking/Mountaineering ;2. Orienteering; 3. Cycling; 4. Free Climbing; 5. Horse riding; 6. Caving; 7. Canyoning; 8. Surviving; 9. Skiing; 10. Hiking with snow rackets; 11. Zorbing; 12. Paragliding; 13. Rafting; 14. Bodyrafting 15. Rowing/ Kayaking; 16. Sailing;17. Sport fishing

Zlatibor or Monastery Raca. The total length of track will be about $420 \mathrm{~km}$ (http://www.taraplanina.com).

Orientation in nature. There are numerous special maps for orienteering made according to international standards. Mt. Tara is one of the most attractive destinations in Serbia where the orienteering fans or professionals may enjoy in extraordinary experience this activity offers.

Rafting. Eighty-year-long tradition of rafting at the river Drina gathers the enthusiasts to this worldly popular adventure. During the events "Drinska regata" and "Spust niz Drinu" or at any time in summer hundreds of boats (less frequently rafts) are found at the river. Rafting is possible from Perucac to Bajina Basta, Rogacica or even to Ljubovija town and it may last for two to four hours or even the whole day (Milanovic, 2006).

Skiing. This destination has three ski centres, two at Mt. Tara and one completely new Iver, about $7 \mathrm{~km}$ from Mokra Gora. Ski centres at Mt. Tara (Radmilovac and Mitrovac) are at 1,0oo $m$ altitude. The first ski centre at Radmilovac, near the Beli bor Hotel, has two ski lifts (for children and beginners and for adult skiers); whereas only children ski lifts are built at the second ski centre. Three ski tracks Iver are $4 \mathrm{~km}$ long and there is also a cable car. It was built in 2007. 
The start of the track (black and red category) is at 1,490 $\mathrm{m}$ and the finish at 1,200 $\mathrm{m}$ of altitude. The construction of ski tracks and a cable car for children is planned at the other side of the mountain top Iver in the near future (Belij, Amidzic, 2006).

Horse riding. Since 2007, numerous horse riding lovers have been able to ride horses at Mt. Tara. National Park Tara founded a mini horse farm at Kaludjerske bare, near Manastirski stanovi. Also, the horse riding school with complementary programmes for tourist, which has been planned, will complete the overall experience of the outdoor area.

Sports fishing. The river Drina with its tributaries and artificial lakes Perucac and Zaovine offers favourable conditions for sports fishing. Attractive waters for fishermen are also Beli Rzav with Konjska reka, Lipovica and Vezanjska reka, the rivers Raca and Derventa, Brusnicki potok, Aluski potok, etc. Clear waters in this preserved area are habitat of numerous species of fresh water fish, among which the most prominent endemic species are: huchen and grayling, carp, chub, barbell, cat fish and rainbow trout. This fishing area is exclusively used for sports fishing purposes (http://www.ribolovci.com).

Sailing and rowing. These seasonal activities are offered to visitors at lakes Perucac and Zaovine and have become more popular recently.

Guidelines for active holiday development. Apart from present activities and facilities offered for active holiday at the destination Mt. Tara and the valley of the river Drina, there are numerous complementary services which may improve the offer and contribute to better living conditions of the local population and development of the region as well. However, it is necessary to develop competitive facilities that would make this destination more appealing in comparison to other destinations not only in Zlatibor tourist region but within national and regional scope. Good practice examples in developed tourist destinations in Europe and the world have shown that there is unlimited number of facilities that may be included in active holiday offer.

To achieve similar effect, only several possibilities would be proposed, i.e. the realisation and practical application of which is the most realistic for current market conditions, as well as for present infrastructure at the destination Mt. Tara and the valley of the river Drina.

Canyon exploration. Zlatibor tourist region, especially destination Mt. Tara and the valley of the river Drina is the area which is probably the most valuable in Serbia with regard to attractiveness of the river canyons. First, there is the impressive canyon of the river Drina, then follow also interesting canyons of the rivers Brusnica, Derventa and Rzav. Therefore, destination Mt. Tara and the valley of the river Drina offer various possibilities for development and popularisation of canyon exploration activity. It is not only the experienced mountaineers and climbers, but also the tourists attracted by the beauty and wilderness of the canyons who arrive to this destination. The waterfalls are especially attractive in this area, such as Mali and Veliki skakavac at the river Rzav and smaller ones at Levrentija and Raca.

Exploration of caves and pits. Although they are not very popular in tourism, numerous caves and pits hide enormous potential in their variety and richness. Among the caves the most beautiful are Perucacka pecina, Soviljacka pecina, Gornja pecina, Bezimena pecina, Milinova and Ljiljacka pecina. Among the pits the most attractive are Krnja jela, Ciganska jama and Ponor in Mitrovac (Romelic, Curcic, 2001).

Flying. Similarly to the facilities offered at Zlatibor and Pester Plateau, the landscape attractiveness and favourable climate at Mt. Tara and its surroundings are adequate base for flying and hang gliding activities to be included into its tourist offer.

Body rafting. Nature lovers, willing to most directly experience and feel the strength of wild rivers, might improve their adventures by rafting without a boat. The only equipment used is a 
life jacket and a helmet. This adventurous activity has already been included in tourist offers in Slovenia and based on their experience similar tours may be applied to our rivers (the Drina, the Lim and the Uvac rivers). Body rafting, as one of the most modern trends in active holiday offers, would attract numerous domestic and foreign adventurers. Since the activity is not financially demanding and prior investment are unnecessary it would became a first class attraction in a short period. In addition, it is nature friendly and would not endanger well preserved rivers. The part of the river Drina after Perucac is suitable for this extreme sport due to its faster flow.

Survival in the nature. Taking into account the human wish to return to the nature, the programmes offering survival in the nature have become a challenging activity. Mt. Tara offers huge possibilities for such activities which most frequently last for 5 to 10 days. Such activities would be permitted only in the controlled areas and under supervision of National Park guides.

Zlatibor. Mt. Zlatibor is an exceptionally wide natural morphological unit, positioned in the zone of Stari Vlah between mountains Tara and Zlatar. It is a gently undulated mountain plateau at average $970 \mathrm{~m}$ of altitude (Markovic, 1980) with vast complexes of colourful mountain pastures and meadows, decorated with individual or smaller groups of often very old trees of Scots pine, fir and spruce and characteristic shallow cut winding riverbeds of brooks and rivulets. Impassable gorges, caves and pits, the real challenge for an active and adventurous holiday maker are situated along the rim of the plateau.

The highest peak of Mt. Zlatibor is Tornik $(1,486 \mathrm{~m})$ which stands over the floral paradise of the mountain with over 1,190 of floral species (Amidzic et al, 2007). The main feature of the Nature Park is its both flat and undulated area. Owing to that feature, Zlatibor plateau baths in sunshine (about 2000 hours a year) and higher percentage of ozone compared to other mountains in Serbia. Therefore Zlatibor is called "a red blood cells factory". The area of mountain massive belongs to river basins of the Drina and the Zapadna Morava. It mainly consists of limestone with numerous pits, caves, precipices, cascades and waterfalls. The Crni Rzav is the largest water course at Mt. Zlatibor. It formed gorges about 30om high (Djuric, Pavlovic, 2005). On the southern slopes of Zlatibor, there is the mighty river Uvac with its dreamlike canyon.

Current offer of active holiday. In tourism, the term Zlatibor is applied to the central plateau about $30 \mathrm{~km}$ long and $12 \mathrm{~km}$ wide, bordered with the hills of Tornik, Cigota, Gradina, Crni vrh, Cavlovac, Viogora and the upper basin of the river Susice (Djuric, Pavlovic, 2005).

Excess building and urbanisation is the consequence of increased demand for tourist products at Zlatibor and unplanned affluence of tourists to this tourist destination. Active holiday has emerged as a successful compromise between tourist economy and nature protection and conservation. Tourist facilities linked to active holiday at Zlatibor are hiking, cycling, orienteering, horse riding, paragliding and skiing. Active holiday is also a complementary service to health tourism and spa/wellness tourism which have been developing within Cigota programme at Zlatibor and intended for loosing weight and improving overall health condition.

Hiking. Terrain configuration, fresh air, optimal humidity, minimal temperature oscillations and plenty of sunshine create ideal conditions for hiking at Zlatibor. Tourists are able to meet the nature of the mountain by hiking on 9 marked trails (Zlatibor ozone trails) with additional cycling and ski trails all the year round. Hiking trails are Zlatibor round and jogging trail, Cigota's 4 trails of health (2 ethno trails and 2 trails to Tornik and Mokra Gora). The trails have been newly marked with sign posts in Serbian and English.

Cycling.Although the mountain is suitable for either free or mountain cycling, the two present trails are incapable of meeting the needs of tourist demand for this activity. There is only one bike rental in the centre of the destination open only in summer. 
Orientation in nature. Out of ten locations in Serbia with thematic orienteering maps, there are only two locations in south-western Serbia, Zlatibor and Tara, attractive for adventurers and those eager to meet the unknown and search for their targets using a map and a compass.

Horse Riding. Another challenging activity for tourists at Zlatibor is horse riding. The experienced tourists may rent a horse for field riding per hour and the beginners may attend riding course within the only horse farm at Zlatibor. The horse farm Zova is a favourite place for the youngest visitors since pony riding is offered there. It is located only $1.5 \mathrm{~km}$ from the centre of Zlatibor.

Flying. Kites and hang gliders are more frequently seen over Zlatibor since it offers excellent conditions for this sport due to the winds from all directions and the terrain configuration allows easy take off and landing. Currently, there is one paragliding club offering courses for individual gliding or with instructor. There are several locations suitable for this adventure: Cigota, Farma, Kriva breza, Cuker, Volovi, Tornik and Gradina.

Skiing. There is 10o-year-long tradition of skiing at Zlatibor. The season in the lowest parts lasts for three months (January, February and March). For beginners there are mild slopes at Obudojevica with one ski lift. For more experienced skiers a ski centre Tornik with four modern ski tracks and three ski lifts is under construction. Tornik is situated at 1,496 m altitude and about $9 \mathrm{~km}$ far from cenral Zlatibor plateau. In the central part of Zlatibor, at the locations Tica polje, Vranjevine and Spomenik, there are ski running and biathlon tracks. Also, there are alternate ski running and biathlon tracks at Murtenica, covered in snow until May. The total length of the tracks is $12.5 \mathrm{~km}$ (TO Zlatibor, 2008).

Zorbing is a sports activity with two participants (zorbers) who compete in moving the zorb balls by walking, rolling, jumping and other types of movements. Zorb is a ball with radius of $3.2 \mathrm{~m}$ made of transparent plastic with another ball with radius of $1.8 \mathrm{~m}$ inside which the zorber enters (www.naslovi.net). Zorbing has been offered since 2006 at Zlatibor, butt only in winter. The terrain for this activity is favourable because of its mild slopes (meadows and pastures) and vast areas which enable prolonged moving of zorbs.

Guidelines for active holiday development. Zlatibor is a popular tourist destination and at the same time the most visited mountain in domestic tourism. However, Zlatibor has been a marginalised destination for foreign visits (1.3\%) (Horwath Consulting, 2006).

The offer would have to be prepared with the aim to establish Zlatibor as the first and the best destination for active holiday for foreign tourists. Therefore, it would be necessary to include the following activities: caves exploration, rowing, zorbing and hiking with snow rackets.

Caves exploration. Karst is one of forming elements of Mt. Zlatibor and it caused several attractive ground forms, predominantly short caves and shallow pits (Djuric, Pavlovic, 2005). These speleological objects are not used for tourism purposes, except for Potpecka pecina which was opened for tourists in 1984. It is situated in the north foot of Zlatibor and its total length is $555 \mathrm{~m}$ with the impressive entrance of $50 \mathrm{~m}$ height and $12 \mathrm{~m}$ width. A more impressive cave than Potpecka pecina is Stopica pecina, one of the largest speleological objects in Serbia, but it has not been used for tourist visits. This river cave is $1,691.5 \mathrm{~m}$ long with a sinking river Trnavski potok flowing through it (Lazarevic, 1994). Stopica pecina might receive first tourists in 2008, since funding from National Investment Fund has been received for the cave's spatial organisation for tourism purposes.

Rowing. There area two artificial lakes at Zlatibor, one in the very centre of the destination -Obudovacko Lake, and the other one in the vicinity - Ribnicko Lake, the waters of which are used as drinking water. Calm waters of the lake in the centre make a perfect place for recrea- 
tion of active holiday makers. The lake is well connected to the traffic infrastructure and surrounded with restaurants. The large area of the lake enables various water sports activities. Rowing should be organised in the form that would not endanger natural and ambience values of the lake and its surroundings. The rowing lessons and boat rentals (as seen at examples of good practice lakes Bled and Bohinj in Slovenia and Balaton in Hungary) have been confirmed as excellent example of meeting the needs of active holiday makers.

Hiking with snow rackets. Owing to favourable terrain configuration totally suitable for the hiking with snow rackets, Zlatibor would improve its current winter offer. The mountain of highest insolation in Serbia may offer ideal conditions for active holiday makers. This activity needs small initial investments and in a very short period it could be introduced into the regular tourist offer.

The Valley of the Uvac river and mountain Zlatar. The Uvac river flows between the mountain Zlatar in the south and mountains Javor and Zlatibor in the north. The mountainous terrain near this river gave it potential for building 3 artificial accumulations with hydro power stations. The first artificial lake at the Uvac river is Sjenicko or Uvacko Lake, with the second highest altitude of $985 \mathrm{~m}$ among the lakes in Serbia. Downstream from Uvacko Lake there is Zlatarsko Lake, the biggest artificial lake in Zlatibor county, with the total length of 23 $\mathrm{km}$ and the area of $18 \mathrm{~km}^{2}$. It is situated north from Zlatar and it was made by making an $83 \mathrm{~m}$ high dam in the Uvac river valley and Hydro-power plants Kokin Brod and Bistrica. The water from Zlatarsko Lake flows to Radojinsko Lake and then through a tunnel of Hydro-power plant Bistrica into the Lim river (www.uvac.org.rs).

Impressive canyon of the Uvac river was first officially protected in 1971 and declared as Special Nature Reserve "Uvac". Within the karst rocks of the cliffs in the canyon of the Uvac there are numerous relief forms among which there are mainly rock shelters, caves and pits. Among the caves the most prominent is the system of Uvac caves the second largest cave system in Serbia with the total length of 6,185 m. (http://www.asak.org.yu/caves/srbdeeplong.php).

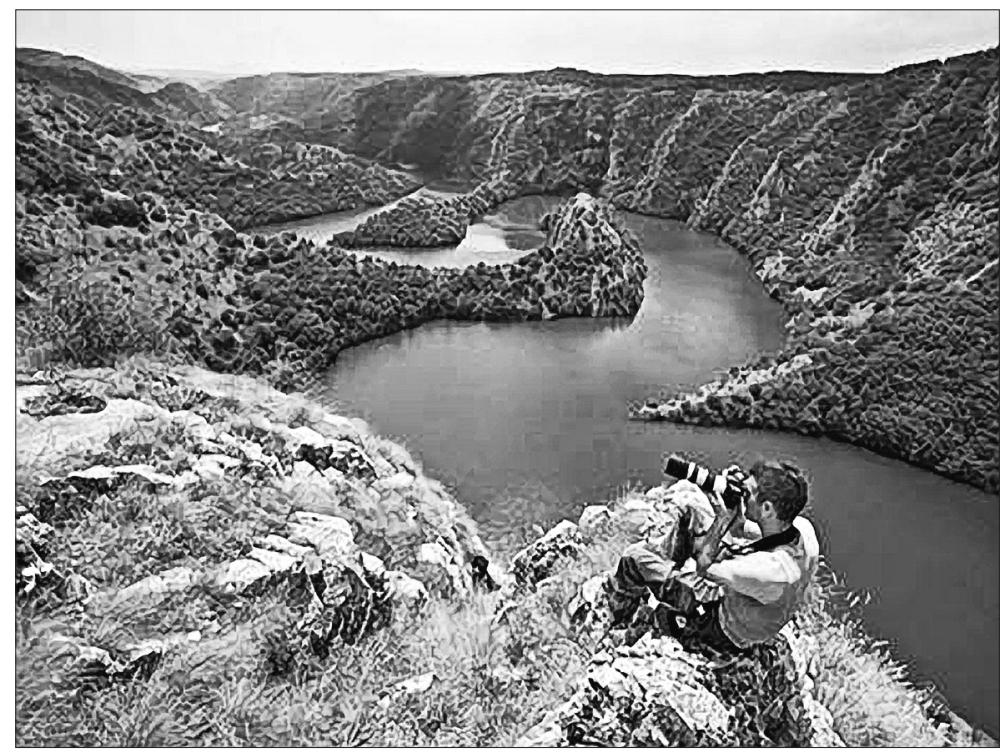

Figure 2. Valley of the Uvac river; Foto: D. Bosnić, 2008 


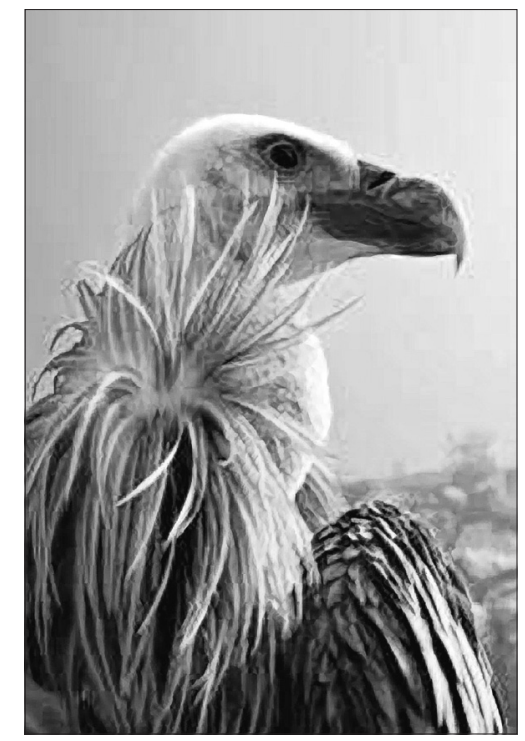

Figure 3. Griffon vulture; www.novavaros.com

Mountain Zlatar is situated between the Uvac river in the east, the Lim river in the west, the Bistrica river in the north and Milesevska river in the south. It stretches on the northwestsoutheast direction and has the total length of $22 \mathrm{~km}$. The highest peak is Golo brdo with altitude of 1,627 $\mathrm{m}$ and the rest of the mountain is between 1,000 and 1,200 $\mathrm{m}$ of altitude.

These morphological features of Mt. Zlatar classify it among the middle height mountains with mild slopes. The climate is a mixture of mountainous and Mediterranean types with a high insolation level and beneficial air filled with turpentine odour and ozone. Due to air circulation and meeting of two air currents, the mountain is called an air spa. There is also the abundance of spuca forests covering about $45 \%$ of the total forests (Romelic, Curcic, 2001).

Current offer of active holiday. Destination the valley of the Uvac river and mountain Zlatar have favourable tourism and geographical position near the regional road from Uzice, via Cajetina, Nova Varos and Prijepolje to the Adriatic sea. Nova Varos is the urban centre of the destination situated at this road which contributes to more frequent visits to the destination.

The former tourism development marginalised the valley of the Uvac river and mountain Zlatar as tourist destinations due to growing popularity of more developed destinations such as Golija, Zlatibor and Tara. With regard to the present condition, the imperative for the future tourism development for this area should be a strategy which would consolidate the local community issues, nature preservation and profit from tourism.

Hiking and mountaineering. The terrain configuration at Mt. Zlatar and its surroundings create excellent conditions for hiking. Attractiveness of nature at the mountain and fascinating valley of the Uvac river with breathtaking sights make altogether a great potential of the destination. Moreover, ideal climate (combination of continental and Mediterranean type) has beneficial influence on human respiratory system, blood and the whole organism. There are organized hiking tours up to Golo brdo $(1,627 \mathrm{~m})$, to the canyon of the Uvac river and lake Zlatar, etc.

Cycling. There are ideal terrains for free biking and mountain cycling all over the mountain. Although there are no marked trails for cycling, it is possible to ride bikes on all the roads and 
mountain trails. High quality bikes can be rented at several points in Nova Varos. The tourist offer of this destination includes cycling tours of villages, monasteries and lakes.

Skiing. There was only one $420 \mathrm{~m}$ long ski lift at Zlatar ski track of $800 \mathrm{~m}$ by the winter season 2007/2008. Owing to National Investment Fund, a new ski centre "Brijezdja", with a modern ski lift for the ski track of $752 \mathrm{~m}$, was built at 1,200 m of altitude between Nova Varos and Babica Brdo (http://www.skijanje.co.yu). Night slalom race is a traditional discipline held in February at the old ski centre "Zlatar" above Nova Varos and mainly attracts the local population. The stays of tourists might be prolonged if the activities of night skiing were organised throughout winter season. It might attract more tourists and prolong their stay.

Horse Riding. Mild slopes and numerous meadows and pastures at Zlatar are highly suitable for horse riding recreation. The school of riding is organised in the tourist centre near Nova Varos.

Rowing and kayaking. The river Uvac together with Uvacko, Zlatarsko and Radoinjsko lake are ideal points for rowing enthusiasts. Calm waters of the Uvac river and its lakes attract numerous tourists who like rowing in smaller or bigger rubber boats or kayaks. Unfortunately, the standard offer is unavailable for rowing or kayaking tours, which are exclusively offered during the event "The Uvac river Regatta" for several days in July and August. However, there is initiative of tourist organisation "Zlatar" to include such activities in to the standard tourist offer.

Flying. The area of Mt. Zlatar is abundant in locations suitable for take off hag gliders. Regardles the wind direction, it is always possible to select an appropriate slope on this mountain. Club of attractive sports and stunts "Zlatarski vukovi” from Nova Varos is always at tourists' disposal for organisation of short flying courses. There are now three hang gliders for the very first experiences in paragliding (www.novavaros.com).

Sports fishing. There are ideal conditions and capacities for this sport at the destination the valley of the Uvac river and mountain Zlatar. It is not only hydorgraphic objects as the Uvac, Uvacko, Zlatarsko and Radoinjsko Lake, but also water courses suitable for sports fishing, such as: the Milesevska River, the Zlatarska River, Dubokodolski brook, the Kosaticka River and Losnica (Romelic, Curcic, 2001).

Guidelines for active holiday development. With the aim of better positioning at the market, the tourist organisation "Zlatar" of the destination the valley of the Uvac River and mountain Zlatar with its seat in Nova Varos will have to decide upon the active holiday facilities which should be included into its tourist offer in the forthcoming period. Another good argument is the presence of transit and health tourism that are complementary forms to special interest tourism and active holiday.

Caves exploration. One of the primary activities to be included into the tourist offer of the destination is the caves exploration. The system of caves at the river Uvac is a natural wealth which is, with minor investments, in need of valorisation. Practically, there are sporadic visits to these caves mainly initiated by small groups of people. The reason probably lies in indecisiveness of the local tourist organisation to prepare the objects for tourism purposes. The objects are only accessible by boat from the river Uvac. At the end of the system of caves, there is a part of the valley suitable for camping.

Canyons exploration. Adventurous exploration of river canyons is a frequent activity for active holiday makers. The river Uvac has been simply predetermined for exploration by inquisitive amateurs, nature lovers or professionals with special intentions. The river is also attractive for being the habitat of griffon vulture (Gyps fulvus). 
Hiking with snow rackets. Mt. Zlatar is a medium height mountain with mild slopes and vast plateaus, favourable climate, long insolation period and a lot of winds. All that would help to commence the activity of hiking with snow rackets. That would also launch Mt. Zlatar at the first position in introducing organised hiking with snow rackets. Practically, only minor investments are necessary at first, for purchasing snow rackets which would be rented in ski centres at Mt. Zlatar.

The Valley of the Lim river. The Lim is the largest tributary of the river Drina and it originates in Prokletije, northeast of Montenegro. Precisely, the river Lim flows out of Plavsko Lake and flows towards the north turning its flow direction towards northeast downstream from Prijepolje. The regional road and the railroad Belgrade-Bar pass through the canyon of the Lim.

The Lim is the longest $(219 \mathrm{~km})$ and most powerful tributary of the Drina. The width and depth of the Lim vary: near Bijelo Polje the width is $45 \mathrm{~m}$ and the depth $2 \mathrm{~m}$; near Prijepolje the width is $60 \mathrm{~m}$ and the depth $2 \mathrm{~m}$; whereas at the confluence with the Drina the width is 90 $\mathrm{m}$ and the depth $5 \mathrm{~m}$ (Gavrilovic, Dukic, 2002). The Lim is the river that carved its valley with alternations of gorges and ravines: Plavsko-gusinska ravine, gorge Sutjeska, Beranska ravine, Tivranska gorge, Bijelopoljska ravine, Dobrakovacka gorge, Brodarevska ravine. Upstream from Priboj, the Lim was dammed for purposes of electric power production and an artificial Potpecko lake was made. Its length is between 17 and $20 \mathrm{~km}$, depending on the water level (Femic, 1999).

The great importance of the river Lim with regard to nature preservation and unique natural phenomena is perceived in two protected natural values: the gorge of the river Milesev$\mathrm{ka}$ and waterfalls of the Sopotnica. The river Milesevka formed a wild karst $24 \mathrm{~km}$ long gorge between the mountains Jadovnik and Zlatar. The Nature Reserve The Gorge of the River Milesevka is at some points $1,230 \mathrm{~m}$ deep and only $4 \mathrm{~m}$ wide. The canyon of the river Milesevka is famous for endemic species Pancic spruce (Matovic, 1986). The waterfalls of the river Sopotnica, a tributary of the Lim, are protected natural monument. The protection is partly due to the abundance of calcareous sediment (bigar) deposited at seven levels in the form of flat fan terraces of various sizes and prominence (Amidzic et al, 2007). The basic value of this natural monument are numerous waterfalls at ridges of calcareous sediment terraces, with additon of old watermills.

Current offer of active holiday. The Lim, a dynamic river, mostly in its upper basin and the surrounding mountains represent an extraordinary potential for present and future employment in tourism sector in the municipalities of Prijepolje and Priboj. Encouraging initiatives have already been undertaken in this area with the aim of sustainable tourism development. Mountaineering at Kamena Gora and Jadovnik, rafting on the Lim, or paragliding over Sopotnica are only the first steps in tourist offer in the area of Prijepolje.

Hiking and mountaineering. Mountains and plateaus on the both banks of the river Lim (Jadovik, Kamena Gora, Jabuka, Babine and Pobijenik) attract numerous tourists with their preserved natural beauties. The tourists frequently explore these areas on foot before or after the rafting tour of the river Lim. Kamena Gora Plateau is intended for hiking and mountaineering. There are 6 marked trails with $80 \mathrm{~km}$ of the total length (Stankovic, 2007). The concept of the trails including difficult and easy parts is adjusted to all categories of mountaineers and hikers. Also, there are well marked trails in Sopotnica with the total length of $100 \mathrm{~km}$. Prijepolje is the second town in Serbia after Belgrade with its own Mountain Rescue Service.

Rafting. The rafting season on the river Lim usually starts in May when the water level is the highest and lasts until October. In May and June there is abundance of water and raft- 
ing is very exciting. In July and later on the river is less dangerous and particularly suitable for beginner rafters. Rafting activities were first organised in 2001. Several travel agents have been offering rafting within one to four day or longer tours. The competitive advantage of the river Lim to the river Tara (the synonym of rafting today) is warmer water and attractiveness. Apart from individual rafting tours on this river, there is also the Lim Regatta taking place every year at the end of May.

Cycling. The terrain configuration at mountains and plateaus in Prijepolje region offers favourable conditions for free biking and mountain cycling. The first tournament in mountain cycling was held in Sopotnica in 1994. This sport is performed in Sopotnica and Kamena gora where there are marked cycling trails.

Free climbing. Sokolica, Gradina, Kamena Gora, the canyon of the Lim and Sopotnica are the locations with marked directions for free climbing. The most attractive activity is climbing the frozen waterfalls. This dangerous sport is only performed by the bravest and the most experienced tourists. Serbia can offer only two locations for ice climbing: the river Kolubara waterfalls and the Sopotnicki waterfalls.

Orienteering. There are three specialised maps for orienteering covering the area of Prijepolje municipality. One is for the town of Prijepolje only and the other two which are more attractive refer to the area of Kamena Gora, Guvnista and Sopotnica. The first orienteering map was made in ratio 1:3500 and the other two in ratio 1:100oo.

Paragliding. The terrain of Prijepolje municipality is suitable for take off and landing for hang gliders. There are numerous take off points with the most popular: Sekulica brdo (940 m), Kosevine (950 m), Sopotnica - Klekova ravan and Kamena Gora - Sveti bor. There is significant contribution to popularisation of paragliding by paragliding club "Beli andjeo". Every year in August the club organises Memorial Cup "Dragoslav Divac" in paragliding (http://www.turizamprijepolje.org.yu).

Sports fishing. The rivers Lim, Milesevka and Sopotnica and Popecko Lake offer favourable conditions for sports fishing. The river Lim and Popecko Lake are rich in various fish species: huchen, grayling, nase, barbel, chub, gudgeon and whitefish, but the tributaries of the river Lim the Milesevka, the Sopotnica, the Dubocica, the Slatinska river, the Seljasnica and the Bistrica are abundant in trout.

Guidelines for active holiday development. Body rafting is an extreme sport at fast and restless waters of the river Lim. Introduction of this activity does not demand large initial investments since the only equipment needed is a life jacket and a helmet. Thus, there are real and justified expectations for this activity to be included in tourist offer for 2008 . These predictions are mainly based on the information about the initiative of travel agents in Prijepolje to include body rafting into their offer for rafting activities.

Caves exploration. There are two speleological objects Kurtova jama and Petnja at Kamena Gora that have not been utilised for tourism purposes. The objects are visited only by professional speleologists and adventurers. The objects are located near the peaks Zecja glava and Badanj (Stankovic, 2007). Although they are rich in cave ornaments, they have been unexplored. It is difficult to predict when and how these objects could be used for tourism purposes, but it is certain that it would improve the attractiveness of the tourist offer for Kamena Gora and the municipality of Prijepolje.

Canyons exploration. Impressive canyons of the rivers Lim, Milesevka and Dubocica with their abundant flora and fauna have become important destinations for nature lovers. The canyon of the river Milesevka is famous for being the habitat of Pancic spruce and chestnut and the canyon of the river Dubocica is famous for yew tree (Femic, 1999). 


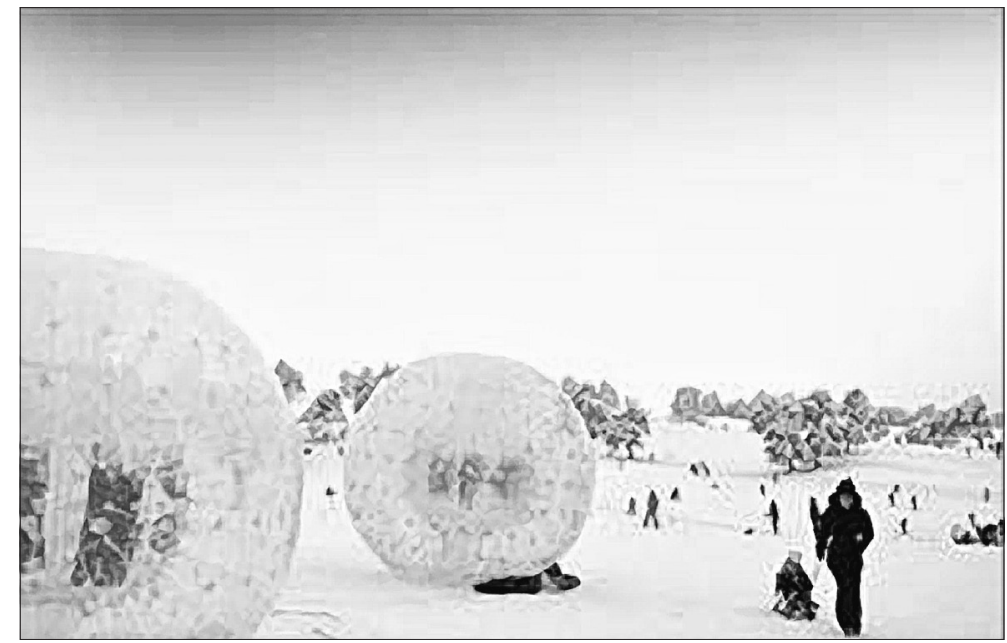

Figure 4. Zorbing on the Zlatibor; www.novavaros.com

Pester Plateau (Pester) is a karst area in Dinaric Alps with average altitude about 1,150 $\mathrm{m}$ (Markovic, 1980). Pester stretches at $20 \mathrm{~km}$ and is bordered by the sources of the rivers Lim, Ibar, Raska and Vapa. It is also surrounded by Giljeva mountain in the west, Pometenik in the north, Stari Kolasin in the east and sources of the rivers Ibar and Lim in the south.

The area of Pester Plateau is covered in pastures with numerous sinking streams. Pestersko and Kostam polje, areas of extraordinary beauty but with rather harsh living conditions, are also part of the Plateau. For centuries the area has been referred to as "Serbian Siberia" for its severe winters and isolation from other parts of Serbia.

Pestersko polje is a protected Special Nature Reserve, covering the area of over $50 \mathrm{~km}^{2}$ at 1,150 $\mathrm{m}$ of altitude and being the largest karst field in the Balkans (Amidzic et al, 2007).

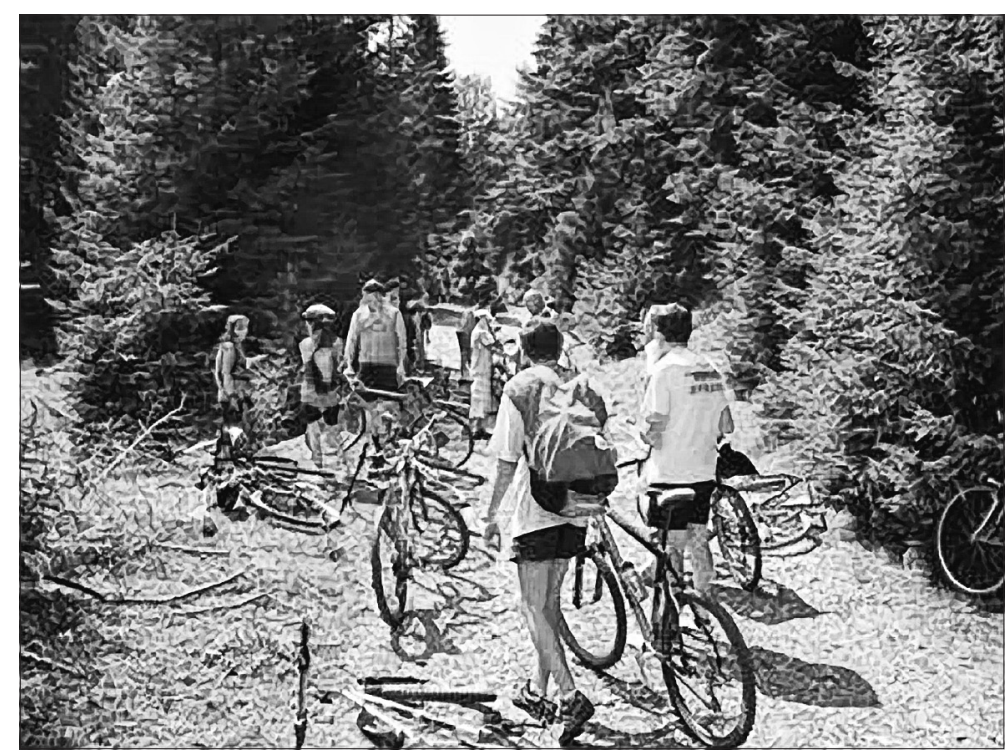

Figure 5. Cycling on the Zlatar; www.zlatibor.com 
Pester is highly attractive for tourism purposes because of its well preserved rural objects and traditional ancillary objects. Sheep and cheese from Sjenica are known worldwide. This part of Serbia is also popular among sports people due to its specific climate, unpolluted air and healthy diet which are ideal for their preparation and frequently visited by sports teams.

Current offer of active holiday and guidelines for active holiday development. At present, mountain Pester does not offer any of active holiday facilities except for skiing. Therefore, we will present the guidelines for active holiday developments based on principles of sustainability which would improve economic condition for the local population.

Tourism is one of the most prosperous forms of improving standard of living in this area which is financially poor but rich in natural resources. The biggest obstacle for smooth development is traffic infrastructure and accommodation facilities. The long isolation period of the area contributed to preservation of its outdoor setting values, which may be used as competitive advantage in tourism development.

There are excellent natural conditions for active holiday and tourism development in general, although it has been neglected for decades due to poor infrastructure and vicinity of popular and highly competitive tourist destinations in Mt. Zlatibor County.

Skiing. The area of Pester in the vicinity of Sjenica offers convenient ski facilities which are growing popular for the long period of snow during winter months. Skiing has been less developed with only one ski lift at Babinjaca, on the road to Nova Varos about $3 \mathrm{~km}$ from Sjenica. Favourable climate would certainly contribute to winter sports development at Pester. Moreover, ski-running near Sjenica attracts more and more winter sport lovers.

Cycling. Pester Plateau offers favourable conditions for development of this type of active holiday making. There are no marked trails, but wide macadam roads between villages may be introduced as starting points for this type of holiday. Frequent ascends and descends, lack of urbanisation and unspoilt nature are ideal prerequisites for introducing cycling into the regular tourist offer in Sjenica and its surroundings.

Horse Riding. The population of Pester has been breeding cattle from the time immemorial because the terrain is mainly pastures and vast grassy areas. Traditionally, high quality horse breeds are bred there with pride. For the purposes of tourism the conditions should be met for a horse farm building and horse rentals.

Flying. Hang gliding or paragliding at Pester Plateau is a real possibility because of the favourable terrain and winds blowing from all directions. Sjenica as the main emissive centre of the destination might in short time become the main paragliding take-off. This extreme activity is becoming more popular among amateurs who mastered short courses in hang gliding. Fast spreading of paragliding is supported by the fact that it does not demand high investments for this activity to be included in the offer of a destination. This is also the advantage for Tourist organisation in Sjenica and individuals interested in introducing paragliding at Pester.

Caves exploration. The cave system of the river Uvac is a huge potential for two destinations in this area, the valley of the river Uvac and mountain Zlatar and Pester Plateau, since it borders both destinations.

Zorbing. Vast pastures and meadows stretching infinitely at Pester make the destination suitable for an adventurous but danger free activity - zorbing. Due to low temperatures in winter, it would be possible to organise zorbing activities only from spring to early autumn. Zorbing demands only small investments, but the income might be high. Meeting Pester by rolling down a hill while strapped inside an extremely large plastic ball would be an extraordinary experience to contribute to popularisation of the destination. 


\section{Conclusion}

Mt. Zlatibor County, or popularly referred to as tourist region of Zlatibor represents one of the most attractive areas in Serbia and at the Balkan Peninsula. The variety of natural values, ambience of settlements and hospitality of the people make this region a promised land for active holiday, as well as other sustainable forms of stays in nature. Gorenska in Slovenia is the example of a successful destination of active holiday, i.e. a good practice example and positive experience which was created by special interest tourism. Regardless the activity (rafting on the Lim river, cycling at Mt. Tara or zorbing at Mt. Pester), the area of Mt. Zlatibor County is as attractive and suitable for active holiday development as any famous specialised active holiday destination in the world.

However, there are restricting factors for further development of active holiday in Mt. Zlatibor County which mainly slow down popularisation of this tourist region at national and regional level. Primarily, among the restricting factors there are underdeveloped traffic infrastructure, inadequate accommodation capacities and lack of unique strategy for active holiday development at both local and regional level.

The most perspective destinations for active holiday in Mt Zlatibor County are Mt. Tara and the valley of the Drina river, Zlatibor, the valley of the Uvac river and Mt. Zlatar, the valley of the Lim river and Pester Plateau. If Mt Zlatibor County succeeded in conducting the plan, bright future not only in tourism would await for it, the results of which would be first felt by the local population. There would be far reaching positive effects regarding the fact that other tourist regions in Serbia would follow the pattern of this region.

\section{References}

Amidzic, L. et al (2007), Protected natural values of Serbia, Ministry of environmental protection / Institute for Nature Conservation of Serbia, Belgrade. (In Serbian)

Belij, S., Amidzic, L., (2006), Concept of ecotourism development in the future biosphere reserve "The Drina", Collection of papers - Tourism valorisation of mountain Tara, Geographical Institute "Jovan Cvijic", Serbian Academy of Sciences and Arts and Sports and tourism centre Bajina Basta, Belgrade. (In Serbian)

Gavrilovic, Lj., Dukic, D., (2002), The rivers of Serbia, Institute for Textbooks and Teaching Aids, Belgrade. (In Serbian)

Djuric, A., Pavlovic, J., (2005), Zlatibor, Tourist Organisation Zlatibor, Zlatibor. (In Serbian)

Ilic, Stankovic, (2006), Geographical position of mountain Tara as a factor in tourism development, Collection of papers - Tourism valorisation of mountain Tara, Geographical Institute "Jovan Cvijic", Serbian Academy of Sciences and Arts and Sports and tourism centre Bajina Basta, Belgrade. (In Serbian)

Lazarevic, R., (1994), Stopica pecina, Assembly of Municipality of Cajetina, Belgrade. (In Serbian)

Markovic, J. Dj., (1980), Regional geography of Socialist Federal Republic of Yugoslavia, Gradjevinska knjiga, Belgrade. (In Serbian)

Matovic, M., (1986), Vegetation in the canyon of the river Milesevka, Glas Polimlja, Prijepolje. (In Serbian)

Milanovic, A., (2006), Hydrological objects of mountain Tara - tourism development perspectives, Collection of papers - Tourism valorisation of mountain Tara, Geographical Institute 
"Jovan Cvijic", Serbian Academy of Sciences and Arts and Sports and tourism centre Bajina Basta, Belgrade. (In Serbian)

Plavsa, J., (2007), Sports and recreational tourism (manuscript), Department of Geography, Tourism and Hotel Management, Faculty of Science, Novi Sad. (In Serbian)

Plavsa, J., Romelic, J., Stojanovic, V., (2006), Sustainable development of tourism in National Park Tara, Collection of papers - Tourism valorisation of mountain Tara, Geographical Institute "Jovan Cvijic" Serbian Academy of Sciences and Arts and Sports and tourism centre Bajina Basta, Belgrade. (In Serbian)

Romelic, J., Curcic, N., (2001), Tourism geography of Yugoslavia, Institute of Geography, Novi Sad. (In Serbian)

Stankovic, M., (2007), Kamena Gora, Centre for sustainable development of Kamena Gora; PSD Kamena Gora, Prijepolje. (In Serbian)

Stankovic, S. M., (2003), Tourism - protection and valorisation, Serbian Geographical Society, Belgrade. (In Serbian)

Stojanovic, V., (2007), Sustainable development of tourism and environment, Department of Geography, Tourism and Hotel Management, Faculty of Science, Novi Sad. (In Serbian)

Sung, H. H., (1997), Active travel, Purdue University, West Lafayette.

Tourism Organisation (TO) of Zlatibor. (In Serbian)

Femic, M., (1999), The area of Prijepolje in space and time, SGD/Museum of Prijepolje, Belgrade. (In Serbian)

Hall, C.M., Page, S.J., (2002), The Geography of Tourism and Recreation - Environment, place and space, Rutledge, London.

Horwath Consulting Zagreb / Faculty of Economics - University of Belgrade, (2006), Strategy of tourism development in the Republic of Serbia, Belgrade. (In Serbian)

Tourism Organisation of Zlatibor, 2008. (In Serbian)

Data of the Statistical office of the Republic of Serbia for 2005. (In Serbian)

Spatial Plan of the Republic of Serbia, (1996), Ministry of Urban Planning and Civil Engineering of the Republic of Serbia, Belgrade. (In Serbian) 